\title{
Issues in training for Essential Maternal Health Care in Indonesia
}

\author{
Abdul Bari Saifuddin
}

\begin{abstract}
Abstrak
Angka Kematian Ibu di Indonesia masih tinggi, yaitu sekitar 390 per 100.000 kelahiran hidup pada tahun 1994. Perkiraan AKI dari beberapa penelitian sejak 1978-1994 menunjukkan penununan yang lamban, walaupun telah dicanangkan bahwa pada akhir Repelita VI angka kematian ibu diharapkan dapat menjadi 225 per 100.000 kelahiran hidup. Upaya penurunan AKI di Indonesia telah banyak dilakukan. Diuraikan tentang kerangka konseptual dari McCarthy dan Maine yang terdiri atas determinan jauh, determinan antara, dan keluaran. Keluaran meliputi proses kehamilan, komplikasi kehamilan dan persalinan, dan kematian/disabilitas. Determinan antara meliputi status kesehatan, status reproduksi, akses pada pelayanan kesehatan, dan perilaku/pemanfaatan pelayanan kesehatan, serta faktor-faktor yang tidak terduga. Determinan jauh meliputi status wanita, status keluarga, dan status masyarakat. Pada bagian terakhir ditinjau tentang peran pelatihan pada Gerakan Safe Motherhood, meliputi pendidikan tenaga kesehatan dan pelatihan lanjutan tenaga kesehatan. Peranan Jaringan Nasional Pelatihan Klinik yang dipelopori oleh POGI yang memperkenalkan Pelatihan Berdasar Kompetensi dalam bidang Keluarga Berencana dan Kesehatan Reproduksi sangat berarti.
\end{abstract}

\begin{abstract}
The Maternal Mortality Ratio (MMR) in Indonesia remains high, i.e. approximately 390 per 100,000 live births. The estimated MMR obtained from the studies from 1978 to 1994 suggests a slow reduction, although it has been determined that by the end of Five Year Plan VI, the MMR is expected to be reduced to 225 per 100,000 live births. The efforts to reduce the MMR in Indonesia have been reasonably made. The conceptual frame work from $M c$ Carthy and Maine, consisting of distant determinants, intermediate determinants, and outcome will be outlined. The outcome includes the process of pregnancy, complication of pregnancy and labor, and mortality/disability. The intermediate determinants include health status, reproductive status, access to health services, health care behavior, and unknown/unpredicted factors. The distant determinants encompasses women's status, family's status in community, and community's status. The last section of this paper reviews the role of the trainings in safe motherhood movement, covering the education of health personnel and the subsequent continuing education. The role of the National Clinical Training Network initiated by POGI, which introduces the Competency Based Training in Family Planning and Reproductive Health is very significant.
\end{abstract}

Keywords: Maternal Mortality Ratio, comprehensive framework, determinants, preservice training, in service training

The Maternal Mortality Rate, or more accurately the Maternal Mortality Ratio (MMR), is one of the indicators for assessing the success of health development. MMR is the key indicator that reflects maternal health status, particularly the mortality risk of pregnant women and for delivery. The target to be achieved in the effort to reduce MMR in Indonesia has been established as a decrease to a MMR of 225 maternal deaths per 100,000 live-births by the end of the 6th Five-Year Development Plan (1994-1999) and 80 maternal deaths per 100,000 live-births by the end of the Second Twenty Five Year, Long-term Development Plan

Department of Obstetrics and Gynecology, Faculty of Medicine, University of Indonesia/Dr. Cipto Mangunkusumo Hospital, Jakarta, Indonesia
(2015) respectively. The corresponding policies and action plans to reduce maternal mortality have also been established. These include the improvement of integrated management at both central and regional levels, the equal provision of health services, an enhancement of health service quality, an optimum increase of basic service resources, the development of appropriate technology, the development of a management information system and community institution activities, social marketing, and operational research for improving the quality of case management. ${ }^{1}$

In accord with these policies, a variety of efforts have been initiated by both the government and the community. Nevertheless, the MMR in Indonesia is still the highest in the Southeast Asian Region. In addition, there exists a wide variation in maternal mortality rates among provinces, even among the districts in any 
given province. However, unlike the MMR, in the case of the infant mortality rate there has been a relatively steep decline from 142 infant death per 100,000 live birth in 1968 to 57 per 100,000 in $1992 .^{2}$

\section{MMR IN INDONESIA}

It is not easy to obtain accurate MMR data in developing countries, particularly in Indonesia, primarily because of the limitation of a vital registration system and the lack of reliable data. Various attempts to obtain this data over a long period of time have been made in Indonesia. Unfortunately, the varying approachs used for data identification, analysis, and scope of coverage has led to a great variety of MMR figures that require very careful interpretation.

Table 1 shows various estimations of MMR in Indonesia, based on a number of studies conducted from 1978 to 1994.

1985 and 1986 Household and Health Survey (HHS) data, using an approach of retrospective data identification and maternal mortality diagnosis with verbal autopsy, estimated Indonesian MMR at 450 maternal deaths per 100,000 live-births. ${ }^{5}$ However, the 1985/1986 HHS sampled households in only seven provinces. Thus this estimated MMR figure can hardly be thought of as a nationwide representation. The retrospective approach is thought to be biased by a tendency for underreporting to the extent that it provides a lower estimation than what is actually the case.
The 1992 HHS, covering 27 provinces of Indonesia, provided two estimations by means of two different approaches. Based on a retrospective calculation, the Indonesian maternal mortality rate was estimated to be 404 maternal deaths per 100,000 live-births. Based on a prospective calculation (follow-up of pregnant women through the completion of the postpartum period), the MMR was estimated to be 455 per 100,000 live-births. ${ }^{8}$

The Indonesian Demographic and Health Survey (IDHS) provided a national MMR estimation of 390 per 100,000 live-births for the period 1989-94, and 360 per live-births for the other period of 1984-89 (sisterhood method, direct), and estimation of 326 per 100,000 live-births for the period earlier then 1980 (sisterhood, indirect). ${ }^{9}$ It should be noted that the sisterhood method is essentially retrospective as well, so that there exists a possibility that the estimated figure is lower than the actual one, particularly for the past periods. In view of this "increasing tendency", the MMR based on the 1994 HHS may be interpreted as suggesting no changes in the maternal mortality rate.

If the similar retrospective approach of the 1985/1986 HHS data is to be compared with that of the $1992 \mathrm{HHS}$, MMR shows a declining tendency from 450 per 100,000 live-births to 404 per live-births. This figure was, however, obtained from two different surveys with a different coverage of provinces, and there may be a probable sampling error in these approaches.

In view of the various estimations elucidated above, it may be concluded that MMR in Indonesia is relatively

Table 1. Estimation of MMR in Indonesia

\begin{tabular}{|c|c|c|c|c|}
\hline Area of study & Est. MMR & Year & Type of study & Reference \\
\hline 12 teaching hospitals & 370 & $1978-80$ & Record study & Chi I-cheng ${ }^{3}$ \\
\hline 6 provinces & 150 & 1980 & Retrospective & HHS $^{*} 1980^{4}$ \\
\hline 7 provinces & 450 & $1985-1986$ & Retrospective & HHS $1985^{5}$ \\
\hline Central Java, rural & 340 & 1987 & Prospective & Agoestina and Soejoenoes $^{6}$ \\
\hline West Java, rural & 490 & 1987 & Sisterhood, indirect & Budiarso et al ${ }^{7}$ \\
\hline \multirow[t]{2}{*}{27 provinces } & 455 & 1991 & Prospective & HHS $1992^{8}$ \\
\hline & 404 & 1991 & Retrospective & HHS $1992^{8}$ \\
\hline \multirow[t]{3}{*}{27 provinces } & 390 & $1989-94$ & Sisterhood, direct & IDHS $^{* *} 1994^{9}$ \\
\hline & 360 & $1984-88$ & Sisterhood, direct & \\
\hline & 326 & $1981-82$ & Sisterhood, indirect & \\
\hline
\end{tabular}

\footnotetext{
* HHS = Households and Health Survey

** IDHS = Indonesian Demographic and Health Survey
} 
very high and still a averages around 400 per 100,000 live-births in the early 1990 s.

\section{EFFORTS TO REDUCE MMR IN INDONESIA}

On June 29 1988, President of the Republic of Indonesia, Suharto, announced the Safe Motherhood movement and called on all sectors and parties to support this movement, the primary objective of which was to reduce MMR. A national meeting was subsequently held in November 1988 with the purpose of enhancing the case and inter-sectoral cooperation between the government and the community. In a further effort to establish national strategies and plans of action to achieve the targeted reduction of MMR already agreed upon, a nationwide assessment was conducted in 1991 by Department of Health, supported by The United Nations Development Program and The World Health Organization. The assessment report has been published in six volumes. ${ }^{10}$

(1) Assessment of Maternal Health Situation and Health Services

(2) Assessment of Socio-cultural Aspects

(3) Assessment of Midwifery education and Practices

(4) An Executive Summary of the Assessment and the Recommended National Strategies

(5) Recommended Plan of Action (1992-1996)

(6) Summary of Recommended Provincial Strategies

Apart from the national assessment, it was necessary to undertake studies leading to the provision of information on the actual efforts made in reducing MMR. The studies already conducted are generally descriptive and have not made use of a comprehensive framework. A comprehensive framework in maternal mortality was developed by McCarthy and Maine and constitutes a further development of thoughts of the preceding researches in safe motherhood and maternal mortality. ${ }^{11}$ McCarthy and Maine organized their framework into three components of maternal mortality processes. The process that is the nearest to maternal mortality is the sequence of events or outputs cumulatively giving rise to disability or mortality. The sequence of these events covers pregnancy, childbirth, and their related complications. A woman must be pregnant and experience some complication of pregnancy or childbirth, or have a preexisting health problem that is aggravated by pregnancy, before her death can be defined as a maternal death. This sequence of events is directly affected by five intermediate determinants, i.e., health status, reproductive status, access to health services, health care behavior/use of health services and unknown or unpredicted factors.

On the other hand, various socio-cultural and economic factors (women's status in family/community, family status in community, community's status) constitute distant determinants that will affect MMR through those intermediate determinants. With this framework in mind, all the efforts aimed to reduce MMR must be undertaken through: (1) the prevention of possible conception; (2) the possible reduction of pregnant women developing pregnancy or delivery complications, and (3) the improvement in the output of pregnant women with complications.

\section{Proximate Determinants}

With the success of Family Planning program, it can be said that the current incidence of pregnancies in Indonesia is relatively lower than in the past. The decline in pregnancy incidence is evident from the decrease of the Total Fertility Rate (TFR) from 5.61 (period of 1967-70, according to Population Census of 1970) to 2,85 (period of 1991-94, according to the 1994 IDHS). ${ }^{9}$ The success of Family Planning program is also reflected in the changes of various variables of proximate determinants affecting a pregnant woman, e.g., the increasing use of contraceptives, first marriage age, and age at first sexual relationship. The 1994 IDHS showed a decline in the proportion of mortality of 15- 49 years old women as maternal mortality, and suggested a decrease of the MMR of 15-49 years old women from 42 maternal mortalities per 100,000 women to 37 per 100,000 .

Without any decline in the MMR, however, the exposure to the possible maternal mortality for women already pregnant remained unchanged. The leading causes of mortality remained the classic triad, i.e., hemorrhage, gestosis, and sepsis, followed by anemia, prolonged labor and abortion.

Table 2 shows the findings of a study by Agoestina and Soejoenoes ${ }^{6}$ in Central Java, which found the Case Fatality Rate to be $35 \%, 19 \%$, and $11 \%$ respectively for retentio placentae, hemorrhage, and sepsis. The $1986 \mathrm{HHS}$, the $1992 \mathrm{HHS}$, and the 1995 HHS documented the complications of delivery: hemorrhage, sepsis, and eclampsia, with almost constant prevalence during the last 8 years. The 1994 IDHS reported a high incidence of pregnancy/delivery being effected by complications (24\%), e.g., prolonged labor, hemorrhage, infection, and eclampsia. ${ }^{9}$ 
Distant

determinants
Intermediate

determinants
Outcomes

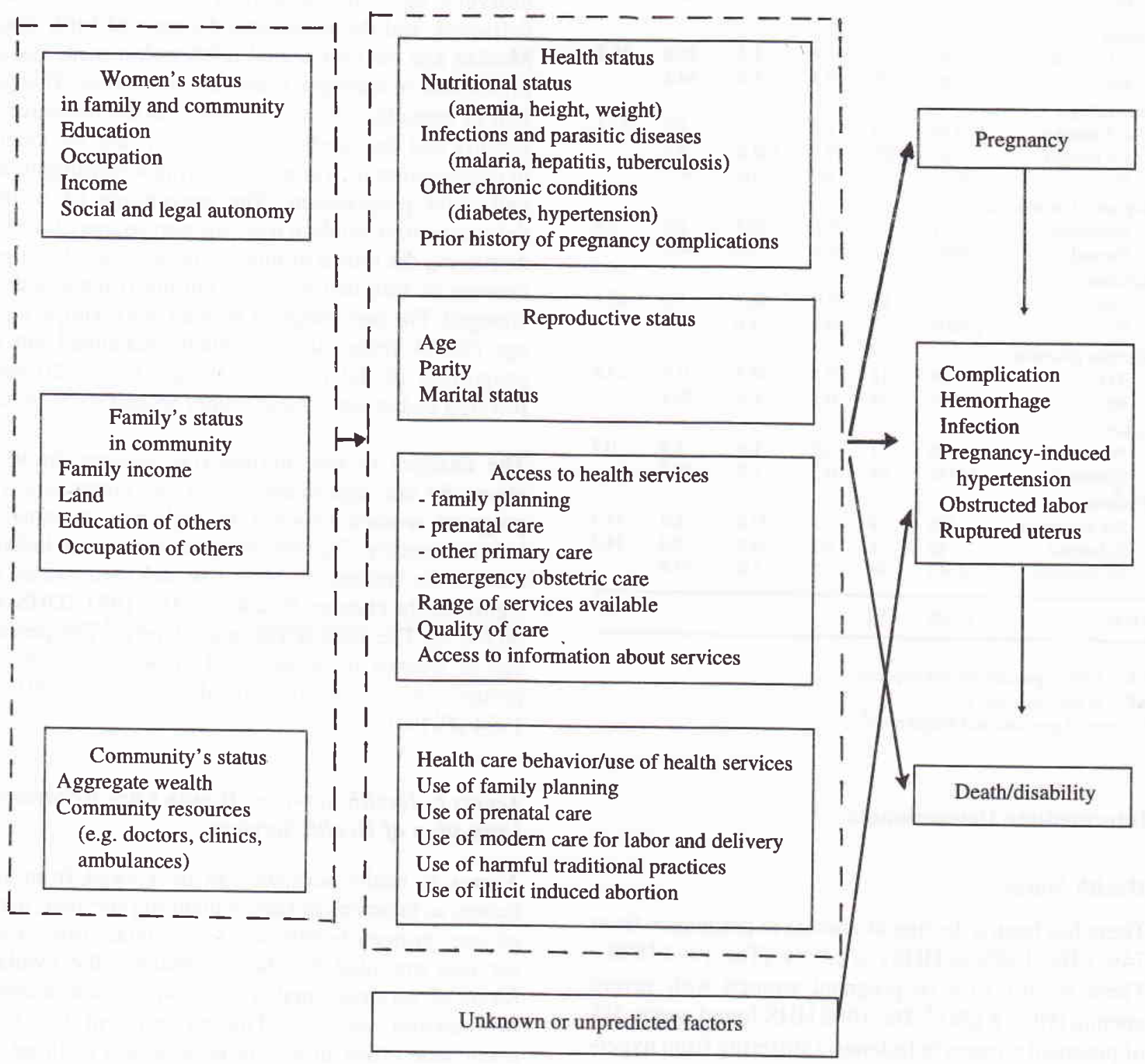

Figure 1. A framework for analyzing the determinants of maternal mortality and morbidity. ${ }^{11}$ 
Table 2. Complication among a sample of pregnant women and deliveries, Central Java, 1989

\begin{tabular}{|c|c|c|c|c|c|c|}
\hline \multirow[t]{2}{*}{ Complication } & \multicolumn{2}{|c|}{ Number } & \multirow[t]{2}{*}{ CFR } & \multirow[t]{2}{*}{ RR } & \multirow{2}{*}{$\begin{array}{c}\% \\
\text { Exposed }\end{array}$} & \multirow[t]{2}{*}{ AR } \\
\hline & Sample & Death & & & & \\
\hline \multicolumn{7}{|l|}{ Anemia } \\
\hline Yes & 270 & 11 & 4,1 & 15,3 & 1,8 & 20,6 \\
\hline No & 14658 & 39 & 0,3 & 1,0 & 98,2 & \\
\hline \multicolumn{7}{|l|}{ Emesis } \\
\hline$<5$ months & 5348 & 22 & 0,4 & 1,4 & 35,8 & 12,7 \\
\hline No & 9580 & 28 & 0,3 & 1,0 & 64,2 & \\
\hline \multicolumn{7}{|l|}{ Hemorrhage } \\
\hline$<5$ months & 110 & 0 & 0,0 & - & 0,7 & 53,4 \\
\hline$>5$ months & 141 & 27 & 19,1 & 122,2 & 0,8 & \\
\hline No & 14677 & 23 & 0,2 & 1,0 & 98,3 & \\
\hline \multicolumn{7}{|c|}{ Rupture of membrane } \\
\hline Premature & 31 & 3 & 9,7 & 30,7 & 0,2 & 5,8 \\
\hline Normal & 14897 & 47 & 0,3 & 1,0 & 98,8 & \\
\hline \multicolumn{7}{|l|}{ Infection } \\
\hline Yes & 123 & 13 & 10,6 & 42,3 & 0,8 & 25,4 \\
\hline No & 14805 & 37 & 0,2 & 1,0 & 99,2 & \\
\hline \multicolumn{7}{|l|}{ Retentio placentae } \\
\hline Yes & 34 & 12 & 35,3 & 138,3 & 0,2 & 23,8 \\
\hline No & 14894 & 38 & 0,3 & 1,0 & 99,8 & \\
\hline \multicolumn{7}{|l|}{ Labor } \\
\hline Prolonged & 190 & 1 & 0,5 & 1,6 & 1,3 & 0,7 \\
\hline Nomal & 14738 & 49 & 0,3 & 1,0 & 98,7 & \\
\hline \multicolumn{7}{|l|}{ Toxemia } \\
\hline Pre-eclampsia & 295 & 8 & 2,7 & 11,6 & 2,0 & 17,3 \\
\hline Eclampsia & 88 & 8 & 9,1 & 38,9 & 0,6 & 18,3 \\
\hline No toxemia & 14545 & 34 & 0,2 & 1,0 & 97,4 & \\
\hline Total & 14928 & 50 & - & - & - & - \\
\hline
\end{tabular}

$\mathrm{RR}=\mathrm{CFR}$ exposed/CFR not exposed

$A R=p(R R-1) /[p(R R-1)+1]$

*Source: Agoestina and Soejoenoes ${ }^{6}$

\section{Intermediate Determinants}

\section{Health Status}

There has been a decline of anemia in pregnancy from $74 \%$ (The $1985 / 86$ HHS) to $63.5 \%$ (The 1992 HHS). There is still $13 \%$ of pregnant women with severe anemia $(\mathrm{Hb}<8 \mathrm{~g} \%) .{ }^{8}$ The 1992 HHS found nearly $5 \%$ of pregnant women in Indonesia suffering from hypertension, with a higher incidence in rural areas than in urban areas $(5.4 \%$ vs $3.9 \%) .{ }^{8}$

The pattern of the causes of general mortality in Indonesia has changed freq!ently in accord with the epidemiologic transition. Degenerative diseases have become all the more evident, while infectious and parasitic diseases still play a part. TBC still has a dominant place, and its contribution to death even increased from $8.6 \%$ (the $1986 \mathrm{HHS}$ ) to $9.8 \%$ (The 1992 HHS). ${ }^{5,8}$

\section{Reproductive Status}

From the 1991 and 1994 IDHSs, it is evident that there is an increase in the first marriage age and in the first delivery age, the reduction of average children delivered, and the increasing distance of birth space. Median age for first sexual relationship rose, and the prevalence of teenager's delivery decreased. This pattern of reproduction has an effect on the reduction of fertility and the number of pregnancy, and the change in composition of women delivering according to age and child progression. The percentage of women delivering first children rose, the percentage of women delivering the fourth or more child decreased, the percentage of safe delivery (2-3 children) remained unchanged. The percentage of women delivering at a safe age (20-34 years) also remained unchanged but the proportion of deliveries at an age below 20 years lowered and at age 35 and higher tended to increase.

The changes in the reproductive pattern discussed above do not significantly alter the composition of pregnant women exposed to high risk maternal or infant mortality. The percentage of women included in one of the groups of high risk deliveries does not significantly change: $67.2 \%$ for The 1991 IDHS and $66.4 \%$ for The 1994 IDHS respectively. ${ }^{9}$ The percentage of women to be included in two, or more, risk groups also remain unchanged: 36\% (The 1991 and 1994 IDHSs). ${ }^{9}$

\section{Access to Health Services, Health Care Behavior/ Utilization of Health Services}

Access to health services can be viewed from such factors as locations of family planning services, prenatal care, primary health care, or essential obstetric care services provided for the community, the available forms of services, quality of services, and access to information services. The government has made reasonable effort to ensure easy access to those services for the community primarily by developing health facilities, multiplying the availability of health personnel and diversifying the kinds of services. The Rural Midwife Program, which aims at posting a midwife in every villages, started by the government in 1992 , may be a breakthrough towards these problems.

The extent of antenatal care coverage for pregnant women has, in point of fact, been broadened. During a 
period of 1979-80, the coverage was $49 \%$ (The 1980 HHS) ${ }^{4}$ but during 1989-94 the percentage has risen to 82\% (The 1994 IDHS). ${ }^{9}$ However, the pattern of delivery assistance has not changed. According to the 1994 IDHS, only $36.5 \%$ of the delivery was assisted by health providers. The remaining were assisted by traditional birth attendants (TBA). A great majority of deliveries took place at home (77\%, The 1994 IDHS). ${ }^{9}$

The IDHS 1994 demonstrates that high risk pregnant women have worse neonatal behavior than those without risks. This also the case with pregnant women with lower level education and living in rural areas. The percentage of high risk pregnant women as described above proved to remain unchanged.

\section{Indirect Determinants}

Although these determinants do not directly affect maternal mortality, socio-cultural, economic, religious, and other factors must be taken into consideration and integrated into the interventions to be implemented.

\section{THE ROLE OF TRAINING IN SAFE MOTHER- HOOD INITIATIVES}

Based on the above discussion, it may be concluded that two main interventions can be implemented in the effort to lower MMR:

- To continue the efforts to prevent pregnancy by means of increasing the availability and use of modern contraceptive services as a long-term solution in reducing MMR.

- To promote the provision and coverage of essential obstetric services in such a way that they are easily accessible to the communities as a more direct approach to lowering MMR.

In order to implement these interventions successfully, it is necessary to have health personnel (human resources) in a sufficient number with adequate qualifications. Health personnel resources currently providing obstetric services consist of consulting obstetricians/ gynecologists, obstetricians/gynecologists, general practitioners, midwives, and traditional birth attendants.

\section{Pre-service Training}

At present, the number of consulting obstetricians/ gynecologists is very limited and generally they serve as academic staff at faculties of medicine.
Obstetricians and gynecologists (members of Indonesian Society of Obstetrics and Gynecology, POGI), at present, are approximately 800 in number with an uneven distribution. About 300 obstetricians and gynecologists reside in Jakarta. The facility closest to the rural population where there might be an Obstetricians and Gynecologist are district hospitals, although it should be made clear that not all district hospitals have obstetricians and gynecologists on staff. Currently, future obstetrician and gynecologists are trained at nine educational institutions of higher learning and now number 350 participants. The graduate obstetricians and gynecologists produced per year range between 60 and 80 .

There are at present 32 faculties of medicine (comprising 15 faculties at state universities and 17 faculties at private universities) in Indonesia, producing an average of 2000 graduates of general practitioners each year. Every graduate is obligated to undertake a mandatory assignment for the government for a period of 1-3 years as non-permanent employee at health centers, which are divided into three categories: "Very outlying", "Outlying" and "Normal" health centers. During their education at medical faculties, it is hoped that the graduates will obtain a capability in essential obstetrics functions as outlined in the Core Curriculum of Faculty of Medicine specified by the Consortium of Health Sciences. ${ }^{12}$ However, as outlined in the Report of $\mathrm{MOH} / \mathrm{UNDP} / \mathrm{WHO}$, it is stated that "There is a wide variation in the uniformity of skills and technical capability among health personnel of the same professional level, particulary those posted in health centers and District Hospitals in the management of pregnancy, delivery and post partum period" ${ }^{13}$

It is also a fact that nearly $60 \%$ of the functions carried out by health center physicians are administrative tasks, e.g. meetings with sub-district leaders and Ministry of Health personnel, as well as providing reports to the Ministry of Health, sub-district leaders, or the National Family Planning Coordinating Board. The clinical functions, particularly essential obstetrics, that the doctor undertakes is consequently limited, with most of these functions carried out by midwives.

Paramedics providing these primary services are midwives. In addition, there are general nurses graduated from nursing schools, nursing academy (a three-year educational program), and nursing diploma courses (those who complete an undergraduate diploma program in nursing). Midwives graduated from a number of educational sources: (1) midwifery schools (these 
schools were closed in 1980), (2) nursing and midwifery schools, (3) Midwifery Training Program-A, (4) Midwifery Training Program-B, and (5) Midwifery Training Program-C.

The Midwifery Training Program is situated in nursing schools. Currently, there exists 118 public nursing schools (this does not include Army nursing schools) and 54 private nursing schools located in 27 provinces. The Midwifery Training Program is established as an acceleration program to produce 54,000 Rural Midwives through 1996. Upon the completion of the acceleration program, The Midwifery Training Program will be continued with the purpose of producing only about 5,000 midwives each year as part of a "maintenance" program. The midwives are coordinated by The Indonesian Midwives Association (IBI), currently with 46,113 members in 282 chapters throughout Indonesia. $^{15}$

Traditional Birth Attendants play a major role in pregnancy and delivery assistance in Indonesia. According to the 1994 IDHS, only $37 \%$ of the pregnancies were assited by health personnel in Indonesia. ${ }^{9}$ The 1991 IDHS showed a percentage of $32 \%$. This means that more than $60 \%$ of pregnancy was not assisted by health personnel. It should be noted that there is no formal training required to be a traditional birth attendant and generally the skills of a traditional birth attendant is handed down by means of informal apprenticeship. At present, the number of traditional birth attendants is approximately 70,000 , and the majority have already gained some basic knowledge and skills such as finding and referring pregnant women, assisting with delivery, postpartum care, and the treatment of high risk newborns, "three clean" delivery assistance, home care, postpartum mother and newborn care, nursing and health care by traditional birth attendant, reports and services for pregnant women, delivery, postpartum, and newborn.

\section{In-service Training}

Today, the great majority of health personnel in Indonesia are those employed under the Ministry of Health, including Non- Permanent Employees. During the period of employment, they are usually provided with opportunity for in-service training, both through the Ministry of Health and through other governmental institutions such as the National Family Planning Coordinating Board (Division of Family Planning Training), as well as other professional organizations (Indonesian Medical Association, Indonesian Mid- wives Association, Indonesian Association of Secure Contraceptives, Indonesian Society of Obstetrics and Gynecology, etc). Faculties of medicine are frequently engaged in launching continuing education in the form of training courses, refreshing courses, seminars, symposia and so forth.

Regretably, the vast majority of these trainings are not standardized and coordinated; they are overlapping in their contents and do not utilize "competency based" training method.

The existing courses held by the Ministry of Health range from managerial/administrative courses to basic clinical skill training, as well as public health courses. Through its Directorate General of Medical Services, the Ministry of Health has conducted a number of courses for health personnel destined to be posted to hospitals. The majority of these courses are held in cooperation with teaching hospitals and professional organizations. Under the coordination of the Directorate of Public Health, these courses last for one to three weeks and provide in-service training for approximately 1,000 midwives each year. The plan is to increase these midwife participants to 4,900 each year.

Since 1994, a Life Saving Skills (LSS) course, comprising 10 modules, has been held in 13 provinces by the Directorate of Family Health. ${ }^{16}$ The 10 modules of this Life Saving Skills Course were adapted from the ACNM and cover:

- Introduction to Maternal Mortality

- Antenatal Risk Assessment and Training

- Monitoring Labor Progress

- Episiotomies and Repair of Lacerations

- Prevention of Treatment of Hemorrhage

- Resuscitation

- Prevention and Management of Sepsis

- Hydration and Rehydration

- Vacuum Extraction

- Neonatal care

During 1994 and 1995, as many as 4,922 Village Midwives were trained through this LSS Course. An assessment of the effectiveness of this LSS training program was conducted in 1995 by Wibowo et al. in Central Java, East Java, South Sulawesi, and West Nusa Tenggara. ${ }^{17} \mathrm{~A}$ similar study was undertaken by Maclean et al. in 13 Indonesian provinces. ${ }^{18}$ These studies arrived at the conclusion that the LSS training was necessary but not quite effective towards enhancing the skills of Village Midwives, particularly when it was related to the effort to lower MMR. It is, there- 
fore, clear that the training should be strengthened, with a change to competency based training. More effort should be directed towards the quality of the training, identification of personnel to be trained, type of skills that need to be trained, and the preparation of the potential trainers, the methods of training, options for training sites for the different modules, the methods by which the competency of the trainees are evaluated both at the beginning and at the end of the training, and so forth. Also, more attention should be focused at the adequacy of training sites in terms of equipment and training materials, trainers, staffing, case load available for practice, and management of the training.

\section{POGI's Role in Strengthening Reproductive Health Training}

Based on findings in the 1992 Joint IUD/Norplant Trainings Assessment ${ }^{14}$ by BKKBN, POGI, and JHPIEGO, it was proposed to develop a unified, standardized, and supervised national clinical training network. This network would be established from already existing, operating clinical training facilities; and would concern itself initially with clinical training for Norplant, IUD, and Infection Prevention (NIIP), as well as providing a Refresher NIP Training Course. Once a system for applying Competency Based Training (CBT) to one area of reproductive health was mastered by a core group of trainers, the intention is to expand CBT through the National Clinical Training Network to other areas of reproductive health. To facilitate change throughout the clinical training network, POGI proposed implementation of a training system which created specific roles for and collaborative relationship among various levels/institutions within the network, including a NRC (National Resource Center), PTCs (Provincial Training Centers), and DTCs (District Training Centers).

The primary role of the NRC is to guide the process of developing nationally agreed upon reproductive health service standards, developing training materials, preparing master expert trainers and clinical trainers, and develop a system of follow up and supervision that should be able to maintain the quality of the clinical training network.

The PTCs' primary role is to standardize district level trainers in clinical skills, train district level trainers in clinical training skills, carry out clinical training for doctors and midwives from the district level, and follow up training at the district level.
The primary role of the DTCs is to carry out clinical training for doctors and midwives from Health Centers and supervise service delivery.

To date much progress has been achieved in realizing the unified and standardized national clinical training network, with the focus initially on Family Planning. Approximately 1,800 service providers have participated in the NIIP Refresher Course, more than 20 expert trainers have proceeded through the Advanced Training Skills Course level, more than 70 clinical traines have been standardized and undergone a Clinical Training Skills course, and more than 1,800 service providers have qualified and are practicing clinical family planning based on the completion of a CBT course. A National Resource Document for Family Planning Services has been completed for use as the standardized resource for Family Planning training and services. A National Resource Center for Clinical Training, located in two sites (Jakarta and Surabaya), and 7 PTCs have been established. Other PTCs have begun to take part in the two step process of service delivery standardization and clinical training skill training and practice. ${ }^{19}$

\section{SUMMARY AND RECOMMENDATIONS}

From the above observations, it may be concluded that the efforts to lowering the MMR -- with a target to bring down the MMR to 225 maternal deaths per 100,000 live-births by the end of the 6th Five Year Development Plan -- will undoubtedly pose an enormous challenge.

The main interventions should be directed at the outcome of conception or pregnancy: reduction of the prevalence of pregnancy related complications and improved in the management of what complications take place. The effort to prevent pregnancy (by means of Family Planning) and curative initiatives (essential obstetric services) must be made in concert and in a professional way. For this reason, the adequate number of health personnel and the optimalization of their skills gained through both pre-service and in-service training constitute an indispensable part in the strategy.

The national clinical training network in Family Planning, comprising a NRC, PTCs and DTCs, developed as models, has proven to be beneficial. ${ }^{19}$ It is hoped that these models can also be used for the clinical training in essential obstetrics, through both pre-service and in-service training. The health personnel as- 
sociated with the outcome (proximate determinants), particularly physicians and midwives, will be able to come away with better skills from this training. In view of the breadth of coverage, a pilot project for Essential Obstetrics at the level of NRC may be necessary, with several PTCs to implement an Essential Obstetrics clinical training project at an initial stage.

Through POGI the obstetricians and gynecologists at the district level, whose number is very limited, should be encouraged to broaden their tasks to include roles such as resource person and initiator in developing improved system of maternal health services at their locations. Also the delegation of authority from obstetricians and gynecologists to general practitioners and midwives in the front-line will provide solutions to the existing geographical and time contraint problems, particularly in emergency situations. Health centers should be able to carry out their functions in essential obstetrics, as recommended by WHO. ${ }^{20}$ On the other hand, the health providers who have proved themselves to be capable to carry out their tasks should receive a reward in the form of credits that can be caulculated in pursuing a higher or continuing education.

The utilization of appropriate and relatively new computer assisted training tools, such as Repro System, will be of benefit in improying the transfer of knowledge, updating trainers, and strengthen planning. Trainees can come to the clinical training site for the purpose of enhancing their clinical skills since the necessary new knowledge has already been acquired through a computer assisted learning program like ModCal, which is also part of Repro System. Using this approach, a great deal of time and money can be saved for basic training activities.

Another factor worth considering is a reorientation of the physician's tasks at health centers. This reorientation could be accomplished by putting more emphasis on clinical functions that include essential obstetrics. Administrative and other non-medical functions should be gradually transfered to other competent health personnel, such as public health graduates that have hitherto been produced in a fair number from five faculties of public health in Indonesia.

\section{REFERENCES}

1. Gunawan N. Kebijaksanaan Departemen Kesehatan tentang pengelolaan kasus obstetri di tingkat pelayanan dasar dalam rangka menunjang upaya Safe Motherhood (Government policy on management of obstetrics cases at primary health services to support Safe Motherhood initiatives). Bandung: VIII POGI Annual Meeting, 1992.

2. Soemantri S. Angka kematian anak, bayi, dan maternal (Child, infant, and maternal mortality). Jakarta: SDKI 1994 Seminar, 1995.

3. Chi I-cheng, Agoestina T, Harbin J. Maternal Mortality in Twelve Teaching Hospitals in Indonesia. An epidemiologic analysis. Int J Gynecol Obstet 1981;19:259-66.

4. Budiarso LR, Putrali J, Muchtaruddin. Laporan dan Statistik SKRT 1980. Jakarta: Balitbangkes RI, 1981.

5. Survei Kesehatan Rumah Tangga 1985. (1985 Health Household Survey). Jakarta: Balitbangkes RI, 1986.

6. Agoestina T, Soejoenoes A. Technical Report on the Study of Matemal and Perinatal Mortality in Central Java. Bandung: BKS Penfin, 1989.

7. Budiarso LR. Maternal Mortality in West Java. Maj Obstet Ginekol Indones. 1991;17:166-72.

8. Survei Kesehatan Rumah Tangga 1992 (1992 Health Household Survey). Jakarta: Balitbangkes RI, 1992.

9. CBS, NFPCB, Ministry of Health, Macro Int. Inc. Indonesian Demographic and Health Survey 1994.

10. Ministry of Health, UNDP, WHO. Safe Motherhood. Volume 1-6 Jakarta, 1991.

11. McCarthy J, Maine D. A Framework for Analyzing the Determinants of Maternal Mortality. Stud Fam Plan. 1991;23:23-33.

12. Departemen Pendidikan dan Kebudayaan RI (Ministry of Education and Culture). Kurikulum Nasional Pendidikan Dokter di Indonesia, 1992.

13. Ministry of Health, UNDP, WHO. Safe Motherhood. Recommended Plan of Action (1992-1996). Volume 5. Jakarta, 1991

14. Saifuddin AB, Affandi B, Djajadilaga, Santoso BI, Fihir IM, Bergthold GD, McIntosh N, Tietjen LG. IUD and Norplant Training Assessment Report. BKKBN, POGI, JHPIEGO; 1992.

15. Annas Y. Continuing Education for Indonesian Midwives. Jakarta: IBI, 1995.

16. Marshall MA, Buffington ST. Life Saving Skill Manual for Midwives. Washington, DC, USA: American College of Nurse Midwives, 1991.

17. Wibowo A et al. Evaluative Study on The Life Saving Skills Trainning for Village Midwives at Central and East Java, South Sulawesi and West Nusa Tenggara, Indonesia. Jakarta: Ministry of Health, University of Indonesia, UNICEF, 1995.

18. Maclean GD, Sweet BR, Tickner VJ. Evaluation of the Effectiveness of the Life Saving Skills Programme for Bidan di Desa in Indonesia. The British Council, 1995.

19. Saifuddin AB, Affandi B, Djajadilaga, Widohariadi, Bimo, Ajello C. Strengthening Indonesia's Reproductive Health Education and Training System. Pre-congress Seminar: Learning without Walls. Bali, 1995.

20. WHO. Care of Mother and Baby at the Health Centre. Geneva, 1994. 